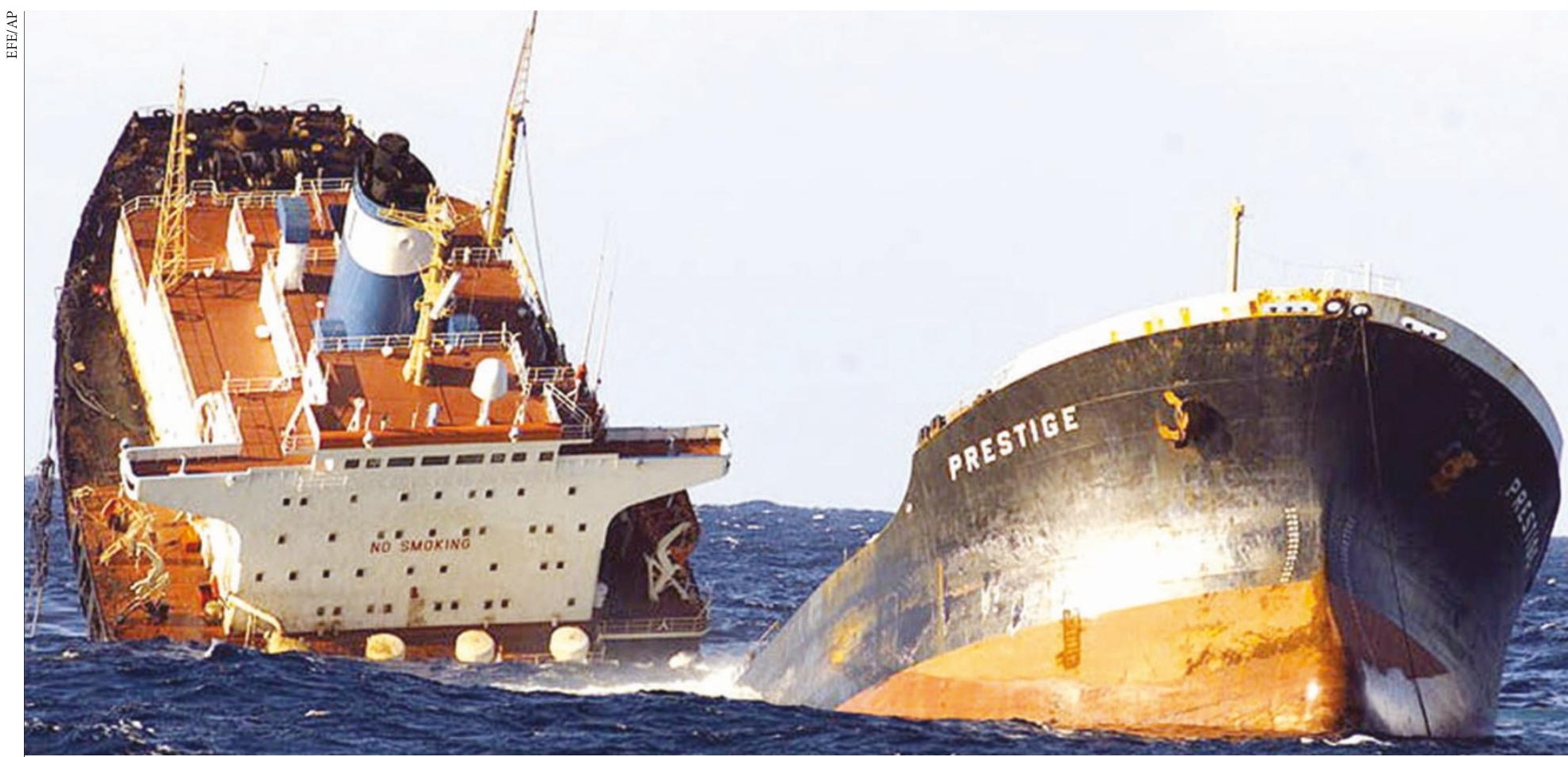

\section{Breaking up is hard to do}

Single-hulled ships are being rushed to the scrapyard in the wake of oil spills such as that of the Prestige. But will breaking them up cause environmental havoc too? Duncan Graham-Rowe finds out. n November 2002, the Prestige oil tanker hit rough weather off the coast of Spain. The ship was badly damaged, the crew air-lifted to safety, and the vessel was led out to sea. Six days later it was torn in two, spewing 77,000 tonnes of oil into the sea. Kilometres of coastline were closed to the public as the thick black liquid spread over beaches and wildlife, prompting fears that the environmental disaster could be even worse than the one in Alaska caused by the Exxon Valdez 13 years earlier.

It's not known exactly what caused the Prestige to crack. What is known is that it was 26 years old and was a single-hulled ship. Such vessels have only a single skin between their cargo and the sea, leaving a slight margin of safety against a spill in case of collision. At the time of the accident, more than 2,200 such ships, many of them old and rusting, had already been earmarked for the scrapyard.

Under regulations drawn up in April 2001 by the International Maritime Organization (IMO) and the European Union, all single-hulled tankers had to be retrofitted or replaced with ships containing two hulls by 2015 - some types as early as 2007. But in the wake of the Prestige accident, those deadlines were cut to 2010 and 2005, respectively.

But this victory for the environment will come at a cost. As the deadlines approach there is a concern that there are not enough ship-breaking yards to cope with the impending deluge of ships. Instead, most of the vessels will end up being scrapped on beaches in India, Bangladesh and China, by workers without access to the tools and equipment that make scrapping safe.

At the same time, some people - includ-

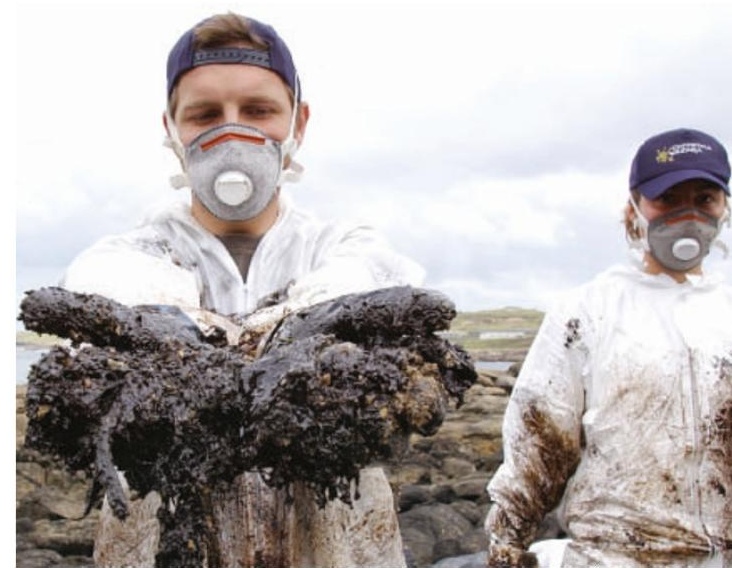

ing both ship owners and environmentalists - argue that this rush to decommission old hulls won't necessarily stop oil spills. A double hull comes with its own problems, says Tim Wilkins, environment manager with Intertanko, an association that represents independent tanker owners. These cost more to maintain because roughly twice the surface area needs to be kept free from corrosion, and gases can build up between hulls, creating the risk of explosion.

\section{Ground rules}

Perhaps more importantly, double hulls are designed to protect against low-velocity impacts, says Wilkins. Yet almost invariably oil spills are caused not by collisions but by running aground, such as happened to the Exxon Valdez and the Erika tanker - which ran aground off the coast of France in 1999. "If both these ships had been double-hulled this would not have prevented the accidents," he says.

No one is arguing that the old, singlehulled ships should simply be allowed to stay 


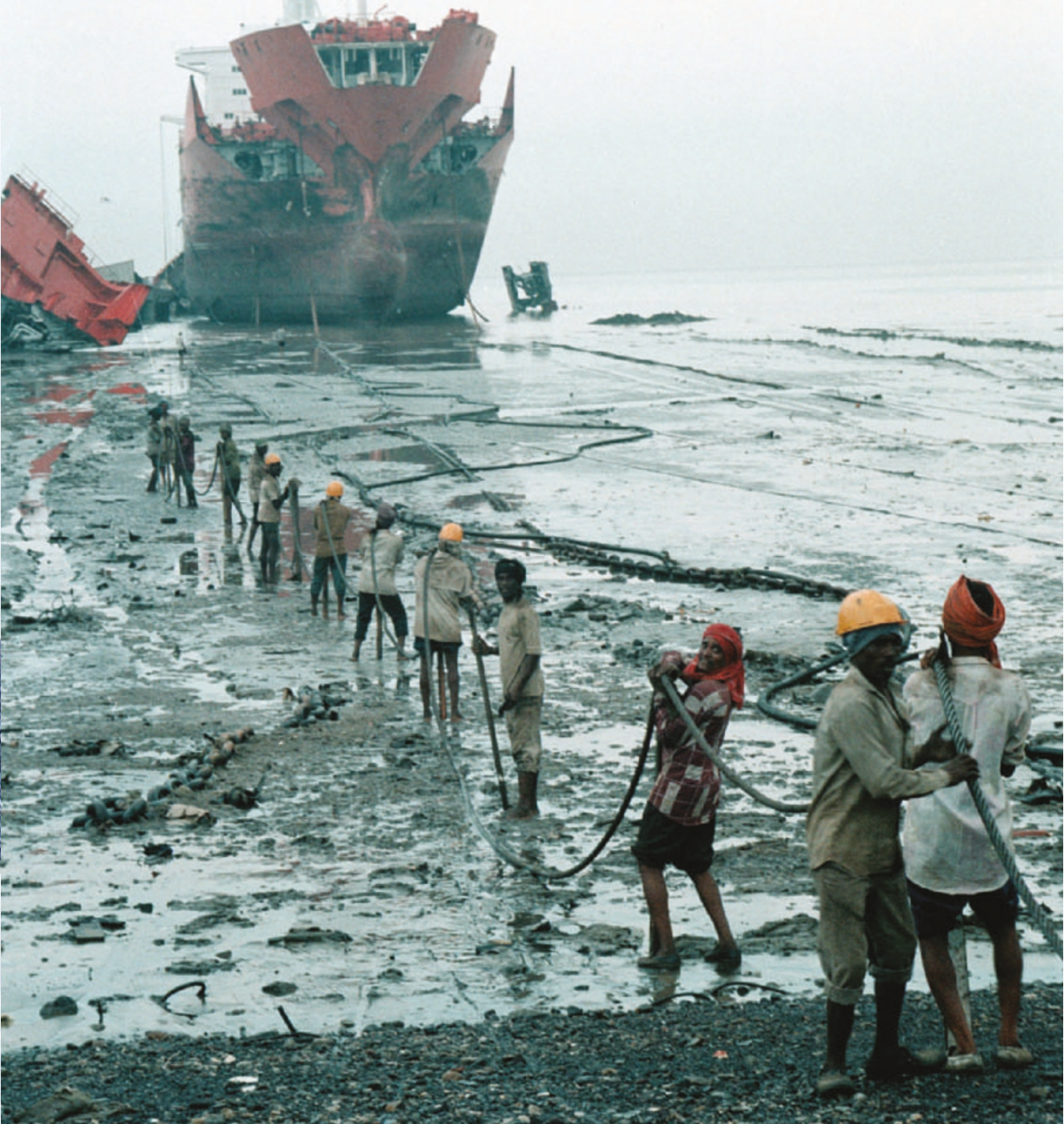

Sinking feeling: the demise of the single-hulled tanker Prestige (top left) left miles of coastline contaminated with oil and led for calls for such vessels to be scrapped quickly. But that could see hundreds of ships recycled on the beaches of Asian countries such as India (above).

at sea. But the rush to decommission them will cause its own problems. "It's a good thing to make tankers safer," says Marietta Harjono, coordinator of Greenpeace's ship-breaking campaign. "But we should be aware if we're simply shifting the pollution."

Oil isn't the only potential pollutant onboard a tanker. Even an empty ship can pose a serious environmental threat. A typical tanker contains heavy metals such as lead, mercury, cadmium and zinc in the paint of its hull - much of it intended to kill barnacles and other life that may try to adhere to the ship's belly. Other hazardous compounds used as antifouling agents include tributyltin, which is toxic to nerve cells and can accumulate in the blood, liver, kidney and brain. Polychlorinated organic compounds, which have been linked to cancer and liver damage, can be found in the insulation of old electrical cables. And asbestos litters old ships as a fire retardant.

In the West, says Harjono, tough regulations ensure the safe disposal of such hazardous materials. Ideally, ships are scrapped in regulated dry docks or controlled quayside facilities where any pollutants released by the dismantling process can be contained.

But in Asia, where $92 \%$ of all ship scrapping takes place, there are precious few of these yards. Three years ago, even before the Prestige sank, Philippe Poirier d'Ange d'Orsay, the now retired president of the Baltic and International Maritime Council (BIMCO) - a global shipping association - called upon China, where most of Asia's dry docks are located, to increase its shipscrapping capacity to help meet the IMO deadlines. But not much seems to have been done.

\section{On the scrapheap}

The reality is that the vast majority of ships are going to be scrapped on beaches in India, China and Bangladesh, says Torben Strand, a senior manager at BIMCO. And it can be difficult to monitor activity there, even where legislation exists.

When ships are scrapped on beaches, their hazardous materials are often just burned in open pyres. Harmful fumes are then released directly into the environment - and into the people breathing the air. Useful materials such as asbestos are often removed without any protective equipment and left to dry on the beach before being resold.

In theory, there are some ship-scrapping facilities in Western countries that could handle some of the load, but there is a definite 'not in my backyard' attitude when it comes to ship breaking, says Harjono. Governments would far rather shuffle the problem to a place where the cost of breaking is cheaper and the pollution problems are farther away.

The US Congress recently appropriated $\$ 16$ million for ship scrapping and now has several yards equipped for breaking. But after a bidding war, the government recently sent four of its ex-Navy 'ghost ships' across the Atlantic to the Able UK ship-breaking yard in Hartlepool. Their arrival was greeted by a mass of protests against what was called a cocktail of hazardous chemicals in the ships, and environmental groups claimed that Able UK did not have the right permits to deal with the 'toxic waste'. Those ships are still sitting in dry-dock in Britain, waiting for permits to roll in. Another nine former US Navy ships scheduled to sail for Britain seem destined to be broken up elsewhere along with nearly 200 others also waiting to be scrapped.

\section{Waste transfer}

Environmental groups argue that shipping such waste to another country breaches the Basel Convention on the export of hazardous waste and so should be prevented, forcing Western countries to clean up their own mess. "It doesn't matter if you export a barrel of asbestos, or transport it as part of a ship's cabin," says Harjono. "The effect is the same." But many ship companies argue that the Basel Convention applies only to the transport of waste and so does not extend to the ships themselves.

Some countries are beginning to take steps that indicate they are aware of their global responsibilities. A European consortium is planning to build a new scrapping facility in the Netherlands to try to cope with the influx of ships, for example. A new type of environmentally friendly ship-recycling yard called an EcoDock is being planned at Eemshaven. Touted as a 'zero pollution' facility, this $€ 45$-million (US\$54-million) yard aims to use about one fifth of the workforce of a typical Chinese yard to scrap ships more safely and much faster than is currently possible.

Pioneered by a non-profit organization called the Stichting Tanker Ontmanteling Platform (STOP), the EcoDock should be able to use heavy cutting machinery to scrap a ship in just 23 days, says STOP chairman Doebren Mulder. In other yards the process usually takes 13 weeks and on the beaches it can take as long as eight months, he says.

If successful, STOP hopes to initiate up to 40 more yards based on this model, and has already begun negotiations with a number of governments to do so. Many of the governments in these talks are again in Asia, where 
ship scrapping is big business and the raw materials — such as scrap steel — are in high demand. Giving Asia a greater capacity to scrap ships safely should be good news. Nevertheless, the first EcoDock won't be complete until July 2006, making it questionable how much of an impact these yards will have on the accelerated decommissioning process.

Across all the ship-breaking facilities available worldwide now, the industry can scrap about 28 million tonnes of steel a year, according to the London-based shipbrokers E. A. Gibson. Technically that is enough to scrap the 175 million tonnes of ships that need to be disposed of by 2010 - if all the vessels are scrapped at a constant rate. In reality, experts say, that is unlikely to happen.

Companies are reluctant to decommission their tankers ahead of the IMO deadlines because the ships are still earning their keep. So shipyards are currently running below capacity, looking for more ships to break, says Wilkins. As the deadlines approach the concern is that there will be a rush to scrap the remaining ships, overburdening the dry docks and forcing most ships onto the seemingly endless stretches of Asian beaches willing to take in more business.

\section{Dirty work}

In Bangladesh alone, more than 100,000 migrant workers are thought to depend on this industry. These are often vulnerable people with few other work options, who work for little more than a US dollar a day in some of the most dangerous conditions imaginable. According to Paul Bailey of the United Nations' International Labour Organization (ILO), ship scrapping is now considered one of the world's most dangerous occupations.

Figures taken from industrialized countries indicate that the rate of accidents and disease in ship breaking is very high compared with other industries. "We can assume that they are as bad, but probably even much worse, in developing countries," says Bailey. Labourers working on beaches receive little training and lack protective clothing or equipment, exposing them to hazardous materials and physical dangers including suffocation, falling debris, fire, explosions and electrocution.

In theory, there are provisions in place to help force this industry to a halt: beach scrapping is set to be phased out by 2012, according to guidelines set up in 2002 under the Basel Convention. But with the industry bringing in so much cash and raw material, it is not clear how this will be achieved.

In the meantime, some governments have tried to deal with the situation by making beach scrapping safer. India, for example, now refuses to allow ships to be scrapped on

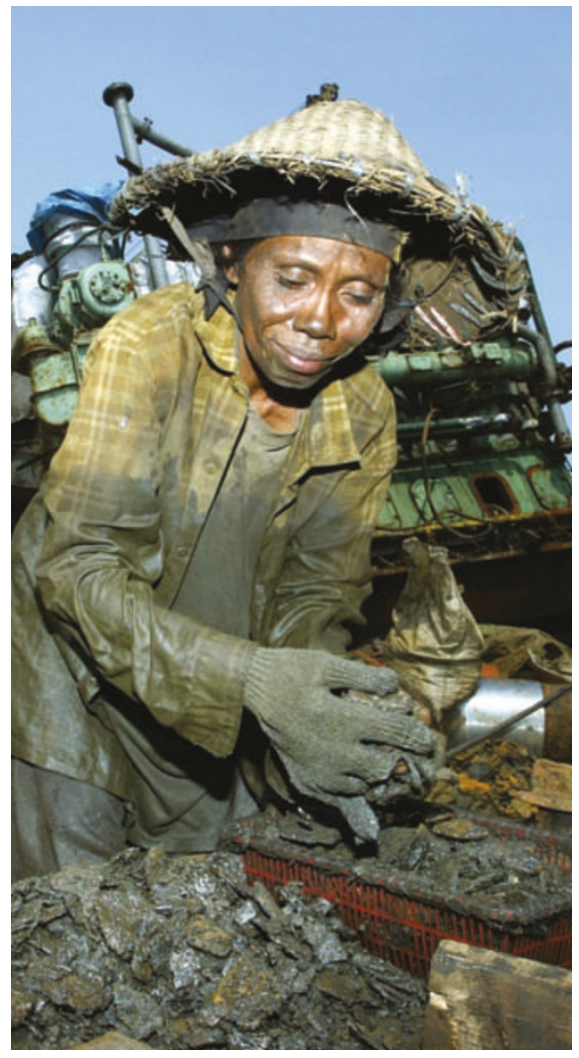

Metal fatigue: an Indonesian woman collects rust during the beach scrapping of a ship.

its shores unless they have been certified as gas-free - meaning that the vessel has been checked for any potentially explosive pockets of gas. This has led to a drop in the number of explosion-related accidents, but has also lost India a lot of business as ship owners have taken their vessels elsewhere.

The ILO and the IMO have also produced guidelines for recycling ships safely. The IMO, for example, has introduced a Green Passport, which involves keeping an inventory of hazardous materials throughout a ship's life. Then, at least, ship breakers will know what they are dealing with when they come to tackle the vessel. The ILO guidelines dvise on the use of protective equipment when dealing with hazardous materials. But these guidelines are voluntary and the passport applies only to new ships.

If the rules and regulations could be made universal across the handful of countries involved in ship scrapping, says Bailey, then they would be much easier to enforce.

"What we want is a level playing field," he says. Alternatively, Western governments could introduce guidelines ensuring that ship owners can only sell their ships to scrapping companies that abide by ILO and IMO guidelines, says Bailey. One solution would be for ship owners to be made responsible for the conditions under which their ships are scrapped, he says.
In the absence of such action, some companies are taking matters into their own hands. The Dutch firm P\&O Nedlloyd already has a policy of only allowing its ships to be scrapped in two dry-dock scrapping facilities in China, both of which abide by ILO guidelines. The company also precleans its ships before handing them over, removing any hazardous materials and providing protective equipment for workers. So far, 19 ships have been scrapped this way at an additional cost of no more than $\$ 100$ per tonne, says Tom Peter Blankestijn, P\&O Nedlloyd's maritime-policy manager. But the company doesn't have any oil tankers, so this only applies to smaller ships.

\section{Clean and dry}

It is possible to scrap ships in an environmentally friendly way, as EcoDock and P\&O Nedlloyd are showing, but it is not the cheapest option. "Some parts of the industry are very much in favour of changing the way ships are scrapped," says Frank StuerLauridsen, chief environmental project manager at Danish engineering consultancy firm COWI, which is investigating the impacts of accelerated ship decommissioning. But, he says, whether a large part of the industry is willing to invest the money to make it happen is another matter.

It is very easy to blame ship owners for taking advantage of cheap scrapping facilities, says Strand, but finding out which ones are clean and safe can be difficult. "We are trying to accommodate concerns about the environment," he says, but the onus should not rest solely on ship owners. "If the ILO wants ship owners to sell to responsible yards then the ILO should supply a list of them," says Strand. This is on the cards, says Bailey.

In the meantime, as the ships queue up to be torn to bits and the deadlines loom, it is worth remembering that the motivation for this rapid response is based largely on politics rather than scientific evidence or environmental concerns, says Stuer-Lauridsen. "It's the high-profile sinking of ships that has driven this," he says.

In the end, the change to double-hulled ships won't be a panacea for the environment, says Harjono. The situation on the beaches where these boats are scrapped is already bad - and is now bound to get worse. The number of ships being ripped apart on the sand has increased by about $25 \%$ each year for the past three years, she claims. The people carrying out the work may depend on the industry and they may be doing the world a service, but they are paying for it dearly. "They are paying with their health, they are paying with their environment and they are paying with their lives. We think that is unacceptable," she says.

Duncan Graham-Rowe is a freelance writer based in Brighton, UK. 